\title{
Релігійно-церковний вимір українського національно-культурного відродження 1917-1921 років: концептуалізація наративу сучасної історіографії
}

\section{Семергей Н. В., Українська медична стоматологічна академія}

У статті розглянуто стан сучасних історичних досліджень із теми українського церковно-релігійного життя у 1917-1921 роках. 3'ясовано, що вчені-історики дійшли висновку, що релігійні мотивації українського національно-культурного відродження, які сформувалися в другій половині ХІХ століття, були вагомим складником національно-демократичної революції початку XX століття, а необхідність вирішення питання «національної церкви» обумовила інтерес усіх державних утворень того часу (Українська Центральна Рада, Українська Держава Павла Скоропадського, Директорія УНР) до процесів інституціювання церковно-релігійних організацій.

Встановлено, що особливість історіографічного дискурсу порушеної теми полягає в ії антологічності та синтетичності, масштабності та методологічності. На основі аналізу тематичного доробку вчених-істориків, виокремлено три групи досліджень, у яких запропоновано розв'язання тих чи тих питань релігійно-церковного виміру українського національно-культурного відродження 1917-1921 років. Перша група об'єднує наукові студії, у яких синтетично розглянуто зміст української церковно-релігійної історії 1917-1921 років. Це праці таких учених, як В. Ульяновський, Б. Андрусишин, В. Ганзуленко, М. Горяч, Б. Гудзяк, О. Турій, А. Колодний, О. Ігнатуша та інші. У другій групі об’єднано наукові праці, що присвячені висвітленню тогочасних державно-церковних відносин (Л. Бабенко, В. Сленський, А. Киридон, В. Пащенко, О. Саган, Л. Филипович, П. Яроцький та інші). Третю групу становлять персоналістичні дослідження, у яких вчені проаналізували внесок тогочасних релігійних діячів у побудову національної церкви, духовне та релігійне відродження України.

Особливу увагу звернено на аналіз істориками впливу церковно-релігійного чинника на тогочасні суспільно-політичні процеси національно-демократичної революції. 3’ясовано, що в сучасному історіографічному наративі висновується думка про те, що представлення церковно-релігійного питання в порядку денному українських державотворчих процесів 1917-1921 років відіграло вагому роль у розвитку концепту «національна церква» та духовно-культурному збагаченні української національної ідентичності.

Ключові слова: Українська національно-демократична революція 1917-1921 років; національно-культурне відродження; історіографія; релігія; церква; «національна церква»; історія церкви; релігійна політика; державно-церковні відносини; релігійне відродження

\section{Religious-church measurement of ukrainian national and cultural revival of 1917-1921: conceptualization of narration of contemporary historiography}

\section{Semerhei N. V., Ukraine medical stomatological academy}

The article researches the state of modern historical research on the topic of Ukrainian church and religious life during 1917-1921. It has been proved that historians came to the conclusion that the religious motivation of the Ukrainian national and cultural revival, which was formed in the second part of the XIXth century, was a significant component of the national and democratic revolution at the beginning of the XXth century, and the need to solve a problem of the «national church» caused the interest of all state institutions of that time (Ukrainian Central Rada, Ukrainian State Pavlo Skoropadskyi, Directoria of the UPR) to the process of church and religious formation.

It is established that peculiarity of the historiographical discourse of the given problem is in its anthology and synthetical character, dimensions and methodology. Based on the analysis of the thematic portfolio of historians, three groups of studies have been identified, which suggest the solution of the problems of the religious and church dimension of the Ukrainian national and cultural revival of 1917-1921.

The first group unites scientific studios, which synthetically consider the content of the Ukrainian church-religious history of 1917-1921. This is, first of all, the three-volume project «Church in the Ukrainian State of 1917-1920», whose authors described the way of church revival in time of Central Rada, Hetman Pavlo Skoropadskyi (V. Ulyanovskyi) and the Directoria of the UPR (B. Andrusyshyn).

The content of religious policy of that time state institutions was also studied by V. Hanzulenko, M. Goryacha, B. Gudziak, A. Turii, A. Kolodnyi, A. Ignatush, and others. It was discovered that scientists devoted considerable attention to the nature of the national renaissance in the Church, to the illumination of the Ministry of theosophy, to the analysis of the work of All-Ukrainian Orthodox Church, to the study of the content of the «Law on Supreme Power in the Ukrainian Autocephalous Orthodox Peacemaking Church», to the characteristics of the All-Ukrainian Church 
Cathedral activity and the formation of the UAOC, to the establishment of the motives of the struggle between the Patriarchate (ROC) and the Ukrainian (autocephalous) churches.

The second group combines scientific works devoted to highlighting the contemporary state and church relations. This is the study of such scientists as L. Babenko, V. Yelenskyi, A. Kyrydon, V. Paschenko, O. Sagan, V. Filipovych, P. Yarotskyi and others. The researchers study the different areas of interaction between church and state, in particular legal, institutional and moral value (A. Kyrydon). The third group consists of the studies in which scientists analyze the contribution of contemporary religious leaders (V. Lypkivskyi, A. Khrapovytskyi, O. Lototskyi, I. Ogienko) to the construction of the national church, the spiritual and religious revival of Ukraine. These are the works of L. Kondratyk, V. Shvedkyi, O. Dudko and others.

Particular attention is drawn to the analysis of contemporary historians of the church and religious factor in the contemporary social and political processes of the national and democratic revolution. It has been proved that in the contemporary historiographical narration the idea that the representation of the church and religious issue in the Ukrainian state-building processes of 1917-1921 played a significant role in the development of the concept of «national church» and the spiritual and cultural revival of Ukrainian national identity.

Keywords: Ukrainian national-democratic revolution of 1917-1921; national and cultural revival; historiography; religion; church; «national church»; church history; religious policy; state-church relations; religious revival

\section{Религиозно-церковное измерение украинского национально-культурного возрождения 1917-1921 годов: концептуализация нарратива современной историографии}

\section{Семергей Н. В., Украинская медицинская стоматологическая академия}

В статье рассмотрено состояние современных исторических исследований по теме украинской церковно-религиозной жизни в 1917-1921 годах. Выяснено, что ученые-историки пришли к выводу, что религиозные мотивации украинского национально-культурного возрождения, которые сформировались во второй половине XIX века, были важной составляющей национально-демократической революции начала XX века, а необходимость решения вопроса о «национальной церкви» обусловила интерес всех государственных образований того времени (Украинская Центральная Рада, Украинская Держава Павла Скоропадского, Директория УНР) к процессам институциализации церковно-религиозных организаций.

Установлено, что особенность историографического дискурса поднятой темы состоит в ее антологичности и синтетичности, масштабности и методологичности. На основе анализа тематических наработок ученых-историков выделено три группы исследований, в которых предложено решение тех или иных вопросов религиозно-церковного измерения украинского национально-культурного возрождения 19171921 годов. Первая группа объединяет научные студии, в которых синтетически рассмотрено содержание украинской церковно-религиозной истории 1917-1921 годов. Это труды таких ученых: В. Ульяновский, Б. Андрусишин, В. Ганзуленко, М. Горяч, Б. Гудзяк, О. Турий, А. Колодный, О. Игнатуша и другие. Во второй группе объединены научные труды, которые освещают церковно-государственные отношения того времени (Л. Бабенко, В. Еленский, А. Киридон, В. Пащенко, О. Саган, Л. Филиппович, П. Яроцкий и другие). Третью группу составляют персоналистические исследования, в которых ученые проанализировали вклад религиозных деятелей того времени в создание национальной церкви, духовное и религиозное возрождение Украины.

Особое внимание обращено на анализ историками влияния церковно-религиозного фактора на общественно-политические процессы национально-демократической революции того времени. Выяснено, что в современном историографическом нарративе сделан вывод о том, что наличие церковно-религиозного вопроса в повестке украинских государственно созидающих процессах 1917-1921 годов сыграло важную роль в развитии концепта «национальная церковь», а также в духовно-культурном обогащении украинской национальной идентичности.

Ключевые слова: Украинская национально-демократическая революция 1917-1921 годов; национально-культурное возрождение; историография; религия; церковь; «национальная церковь»; история церкви; религиозная политика; государственно-церковные отношения; религиозное возрождение 


\section{Постановка проблеми.}

гогодні, укотре за добу національної незалежності України, актуально й гостро постає питання помісності української православної церкви, упевненіше звучить громадянська вимога надання їй рівного статусу в родині світового православ'я. Такі процеси цілком закономірні, адже суспільство все більше усвідомлює той факт, що релігія й церква $€$ необхідним складником побудови держави і громадянських інститутів, відіграє роль ціннісно-смислового фундаменту духовно-культурного й національного відродження. Для правильного розуміння сучасних внутрішньоцерковних процесів і державно-церковних взаємин важливе значення має наукове осмислення їх історичних витоків, історико-культурний аналіз та методологічно адекватна оцінка ролі церковно-релігійного чинника в історії державного будівництва України. Появі таких студій значно сприяли процеси осучаснення методології української історичної науки на основі цивілізаційного та соціокультурного інструментаріїв, а також подолання радянських штампів та атеїстичних стереотипів у відтворенні релігійно-культурного змісту української національної історії. Нові функції сучасної історіографії вимагають систематизації та осмислення існуючого доробку з теми церковно-релігійного життя України в добу національно-демократичної революції 1917-1921 років, що сприятиме актуалізації та реабілітації сутнісної ролі релігії та церкви в сучасних соціокультурних, громадсько-політичних і зовнішньоінтеграційних стратегіях країни.

\section{Аналіз досліджень і публікацій.}

Вивчення релігійно-церковного виміру української національної історії першої третини XX століття в сучасній історичній науці представлено достатньо широко. У той же час аналіз значного масиву історіографії проблеми не набув статусу предмета окремого дослідження. Історіографічна компонента цієї теми представлена лише описами стану розробки проблеми в історичних та історико-релігієзнавчих студіях, що присвячені розкриттю тих чи тих аспектів церковно-релігійної історії доби української національно-демократичної революції. Це праці А. Киридон, В. Ульяновського, Б. Андрусишина, А. Колодного, Л. Бабенко, В. Пащенка, Л. Филипович, П. Яроцького, Л. Кондратика та інших. Зверталася до розгляду історіографії релігійно-церковного життя доби українського національно-культурного відродження й авторка цієї статті [6].
Мета дослідження полягає у з'ясуванні змісту процесу наукового осмислення сутності релігійно-церковного життя в період української національно-демократичної революції 1917-1921 років. Завдання цієї студії ми бачимо в систематизації та аналізі надбань історіографічного досвіду з ключових питань розвитку релігії та церкви означеного періоду, визначенні їхнього впливу на національно-державницьку свідомість і духовність українського народу, а також в окресленні пропозицій щодо перспектив вивчення цієї теми.

\section{Виклад основного матеріалу.}

У програмі державотворення, що була запропонована всіма державними утвореннями доби української національно-демократичної революції 1917-1921 років (Українська Центральна Рада, Українська Держава Павла Скоропадського, Директорія УНР), особлива увага зверталася на вирішення питання «національної церкви» та облаштування державно-церковних відносин. У цьому виявилася тяглість і безперервність релігійного змісту українського національно-культурного відродження, що розпочалося у другій половині XIX століття. Так, ставлення Української Центральної Ради до вирішення всього спектру церковно-релігійних проблем було засвідчено у виданому нею третьому універсалі, де містилися положення щодо облаштування церкви, а також у скликанні Всеукраїнського Православного Церковного Собору. Релігійна політика Гетьманату Павла Скоропадського виявилася в утворенні Міністерства ісповідань (очільники В. Зіньківський, О. Лотоцький, I. Огієнко) та в продовженні роботи Всеукраїнського Православного Собору. Натомість заходи Директорії УНР у справі вирішення релігійного питання полягали в ухваленні «Закону про Верховну Владу в Українській Автокефальній Православній Миротворчій Церкві», проведенні Всеукраїнського Церковного Собору та утворенні УАПЦ на чолі з В. Липківським. Усі ці та багато інших аспектів українського церковно-релігійного життя знайшли відображення в численних студіях з історії церкви та релігії в Україні, аналіз яких дає змогу виокремити три тематичні групи історичних досліджень.

У першій групі нами об'єднано наукові студії, у яких синтетично розглянуто зміст української церковно-релігійної історії 1917-1921 років. Це, насамперед, тритомний видавничий проект «Церква в Українській Державі 1917-1920 рр.», автори якого розставили акценти, запропонували багатий історичний фактаж і системно розгляну- 
ли зміст українського церковного відродження за доби Центральної Ради, Гетьманату Павла Скоропадського (В. Ульяновський) $[9 ; 10]$ та Директорії УНР (Б. Андрусишин) [1]. Цінними були висновки відомого історика церкви В. Ульяновського, який, цілісно проаналізувавши сутність релігійної політики Української Центральної Ради та Гетьманату, дійшов висновку про те, що церковним питанням приділялася винятково велика увага. Держава ставилася до церкви, як до впливової інституції. Найголовнішими стали питання статусу церкви та іiї юрисдикційної самодостатності. Державно-церковні відносини залишалися стабільними, зовні - толерантними $[9$, с. $315-316]$.

Суттєве значення для розкриття змісту релігійно-церковного життя досліджуваного періоду становив цілісний і системний підхід В. Ульяновського до висвітлення церковної історії доби Української Центральної Ради та Гетьманату. Учений ретельно й скрупульозно проаналізував діяльність Всеукраїнського Церковного Собору, запропонував оцінку питанням, що були порушені під час його сесій, вивчив ідеї та принципи діяльності Міністерства ісповідань, що функціонувало в державному апараті Гетьманату Павла Скоропадського, проаналізував його політику не лише щодо православної церкви, але й по відношенню до римо-католицької, греко-католицької та протестантських конфесій [9-10].

Натомість релігійна політика Директорії УНР стала предметом досліджень Б. Андрусишина. Учений грунтовно проаналізував структуру та основні напрями діяльності Міністерства ісповідань, звернув увагу на проблему українізації церкви, духовної освіти, охорону пам'яток церковної старовини тощо. Особливий інтерес становлять наукові висновки дослідника щодо міжнародного визнання проголошеної Директорією УНР автокефалії української православної церкви. Б. Андрусишин грунтовно дослідив місію О. Лотоцького до Константинополя, виокремив та проаналізував причини іï невдачі, звернув увагу на $\dddot{1}$ історичне значення та позитивний міжнародний резонанс [1, с. 52-62].

Зміст релігійної політики тогочасних державних утворень також розглядали В. Ганзуленко, М. Горяча, Б. Гудзяк, О. Турій, А. Колодний, О. Ігнатуша та інші. Предметом наукових зацікавлень учених були ціннісні виміри релігійної політики тогочасних державних утворень, рівень релігійності населення та його ставлення до «національної церкви», організаційні та ін- ституційні засади діяльності релігійних організацій, напрями політики УЦР, Гетьманату та Директорії щодо вирішення церковно-релігійних проблем.

Окремий масив досліджень істориків присвячений аналізу тогочасних державно-церковних відносин. Ми об'єднуємо ці студії в другу групу наукових праць. Це роботи таких учених, як Л. Бабенко, В. Сленський, А. Киридон, В. Пащенко, О. Саган, Л. Филипович, М. Щербань, П. Яроцький та інші. Беззаперечний пріоритет у висвітленні питань, що пов'язані з історією державно-церковних відносин, належить А. Киридон. Особливістю методології ученої щодо аналізу складної взаємодії церкви і держави у 1917-1921 роках стало структурування дослідження за трьома рівнями: правовий, інституційний і морально-ціннісний [4]. Учена насамперед досліджує регламентованість релігійно-церковного життя та з'ясовує статус церкви в законодавчих актах Української Центральної Ради, Гетьманату та Директорії УНР. У цьому контексті цінними стали висновки А. Киридон про те, що відстороненість владних структур чи певний вакуум, який створився навколо церкви на початок діяльності Української Центральнї Ради, активізував рух за оновлення релігійно-церковного життя й пошук шляхів власного виживання церкви. Відтак вона мала вирішувати низку нагальних проблем організаційного, інституційного та діяльнісного характеру. Революційний злам 1917 року каталізував чи призвів до необхідності реструктурування трьох основних форм активності ортодоксальної церкви - політичної, суспільної та внутрішньо-організаційної $[5$, с. $28 ; 35]$. Правове закріплення статусу церкви відбувалося через ухвалення конституційних актів і спеціальних законодавчих постанов [2, с. 167].

Далі А. Киридон розглядала інституційну компоненту державно-церковних відносин - систему органів влади, що регулювали вирішення релігійних питань. Вона підкреслювала, що основна установа - Міністерство ісповідань - мала досить ефективну структуру: департамент загальних справ, департамент православної церкви, департамент інослав'я та іновір'я, департамент духовної освіти [4, с. 254-255]. Загалом учені підкреслюють, що за усіх форм організації влади, упродовж 1917-1921 років існував окремий державний орган, що займався релігійними питаннями: Департамент ісповідань, Міністерство ісповідань, Міністерство культів [2, с. 167]. 
У висвітленні змісту державно-церковних відносин А. Киридон звертала увагу й на морально-ціннісний аспект, який, на думку вченої, полягав в особистому ставленні керівників тогочасних державних установ до віри та релігії. Так, наприклад, вона зазначала, що П. Скоропадський був глибоко віруючою людиною та православним християнином, а відтак намагався гармонізувати відносини держави та церкви [4, с. 256-257].

Значний пласт історичних досліджень із порушеної тематики присвячений висвітленню відносин більшовиків і радянської влади з християнською церквою. Це праці Л. Бабенко, В. Сленського, О. Ігнатуші, А. Киридон [3], В. Пащенка, М. Щербаня [12] та інших. Учені звертають увагу на те, що релігійна політика більшовиків в Україні активно використовувала тоталітарні методи антицерковної боротьби. Звичними для них стали адміністративний тиск на духовенство, репресивно-каральні методи, антирелігійна пропаганда, дискредитація церкви та знищення іiі матеріальної основи тощо [13, с. 190-192].

Третю групу становлять персоналістичні дослідження, в яких учені проаналізували внесок тогочасних релігійних діячів у побудову національної церкви, духовне та релігійне відродження України. Мова йде про церковно-релігійну діяльність митрополита Київського Антонія (Храповицького), митрополита УАПЦ Василя Липківського, міністрів ісповідань О. Лотоцького, В. Зіньківського та І. Огієнка. Так, релігієзнавчим ідеям О. Лотоцького (1870-1939 роки) - історика церкви, вченого, громадсько-політичного діяча, міністра ісповідань Гетьманату Павла Скоропадського присвячені праці В. Ульяновського [10], В. Швидкого [11], Л. Кондратика та інших. Окреме місце в наукових пошуках сучасних учених належить релігієзнавчій спадщині В. Липинського (1882-1931 роки) - видатного історика та суспільно-політичного діяча. Виокремлення та аналіз її положень був предметом досліджень таких учених: Л. Кондратик, О. Бучма, С. Кагамлик, Ю. Марченко, І. Передерій та інших. Дослідники зазначають, що релігієзнавчі пошуки В. Липинського були тісно пов'язаними 3 містицизмом. Релігія, на думку мислителя, $\epsilon$ формою містицизму, ірраціональною вірою в Бога. У той же час релігія уможливлює досконалі форми соціального й морального життя, $\epsilon$ чинником активізації людської діяльності.

Предметом сучасного історичного дискурсу $є$ й вивчення релігієзнавних ідей і практик I. Огієнка (1882-1972 роки) - ученого, церков- ного, державного, громадського діяча, літературознавця, ректора, провославного митрополита та історика української церкви. Це праці таких дослідників, як В. Ляхоцький, I. Тюрменко, М. Тимошик, 3. Тіменик, А. Марушкевич, І. Преловська, Є. Сохацька та інші. У центрі їхньої уваги - релігієзнавча думка I. Огієнка, його наукові підходи до дослідження історії української церкви, розуміння релігії у контексті христоцентризму та апології православ'я. Учені підкреслюють, що, відповідно до концепції І. Огієнка, церква $\epsilon$ національною за змістом і характером своєї діяльності, а народ - провідною силою церковного життя.

Також до цієї групи слід зарахувати й наукові праці, у яких висвітлено релігієзнавчі погляди видатних державних і культурних діячів доби української національно-демократичної революції, зокрема О. Бочковського, В. Винниченка, М. Грушевського, П. Скоропадського, А. Річинського, М. Шаповала та інших [8]. Історики зазначають, що релігієзнавча спадщина початку XX століття була органічним складником українського національно-культурного відродження та відіграла вагому роль у підготовці широкого релігійного підгрунтя формування української державності.

Істотне значення для висвітлення українського церковно-релігійного життя 1917-1921 років становлять студії, що присвячені аналізу регіональних аспектів функціонування церкви, a також характеристиці церковно-релігійного повсякдення [7]. Такі дослідження дають змогу побачити рівень і характер тогочасної церковної організації в регіонах, з'ясувати ставлення населення до релігії, ступінь легітимації церковно-релігійної парадигми серед українства.

Історики акцентують увагу й на тому, що церква і релігія відіграли не лише позитивну роль у національно-демократичній революції 1917-1921 років. Так, сучасна вчена В. Ганзуленко зазначала: «Відсутність чіткої релігійної політики стосовно взаємодії Української держави з конфесіями, що не мали загальнодержавного значення, сприяла, 3 одного боку, непорозумінню серед релігійних громад (інколи навіть відверто ворожому ставленню між ними), а з іншого - було втрачено можливість об'єднання різного за віросповіданням населення заради розбудови самостійної української держави» [2, с. 167].

\section{Висновки.}

Звернення українських істориків до висвітлення релігійно-церковного змісту українського 
національно-культурного і державно-політичного відродження 1917-1921 років свідчить про повернення історичної науки до національного й цивілізаційного підходів у відтворенні українського історичного процесу. У сучасній історіографії обгрунтовано положення про те, що вплив церковно-релігійного чинника на тогочасні суспільно-політичні процеси національно-демократичної революції був винятковий і відіграв вагому роль для розвитку сучасного етапу побудови української національної церкви. Тематичний ландшафт сучасних історичних досліджень маркований темами релігійної політики Української Центральної Ради, Гетьманату Павла Скоропадського та Директорії УНР, державно-церковних відносин, питаннями, що пов'язані з висвітленням ідейно-принципових і ціннісно-смислових аспектів релігійного життя, діяльністю релігійних і церковних лідерів, станом римо- та греко-католицької, а також про- тестантської церков. Значної уваги в сучасних релігієзнавчих студіях приділено з'ясуванню питань української автокефалії, вивченню заходів тогочасних державних утворень щодо визнання української національної церкви на міжнародній церковній і політичній арені. Спільною позицією вчених $є$ думка про те, що представлення церковно-релігійного питання в українських державотворчих процесах 1917-1921 років відіграло значну роль у розвитку концепту «національна церква» та духовно-культурному збагаченні української національної ідентичності.

Аналіз історіографічного досвіду церковно-релігійного виміру української історії 19171921 років не вичерпує усього масштабу порушеної теми. Перспективними для вивчення $\epsilon$ історіографічні сюжети щодо висвітлення діяльності окремих органів церковної влади, ініціатив релігійно-церковних лідерів, а також регіональні аспекти релігійного відродження.

\section{БІБІЛІОГРАФІЧНІ ПОСИЛАННЯ}

1. Андрусишин Б. І. Церква в Українській Державі 1917-1920 pр. (доба Директорії УНР) / Б. І. Андрусишин. - Київ: Либідь 1997. - 176 с.

2. Ганзуленко В. П. Українська Держава 1917-1920 рр.: проблема вирішення релігійного питання / В. П. Ганзуленко // Наукові праці історичного факультету Запорізького державного університету. - 2007. - Вип. ХХІ. - С. 165-167.

3. Киридон А. Державно-церковні відносини в Радянській Україні 1920-х - 1930-х років : соціальний вимір / А. Киридон // Проблеми історії України: факти, судження, пошуки. - 2004. - Вип. 12. - С. 234-256.

4. Киридон А. М. Релігійно-церковне життя в період Гетьманату: проблемне поле взаємодії / А. М. Киридон // Національна та історична пам'ять. - 2013. - Вип. 7. - С. 252-259.

5. Киридон А. М. Церква в умовах революційного зламу 1917 року / А. М. Киридон // Українська національна революція 1917-1921 років крізь призму сучасності (до 100-річчя подіі): зб. наук. ст., матеріалів, тез учасників наук.-метод. сем., 2 березня 2017 р. - Полтава: 2017. - С. 24-35.

6. Семергей Н. В. Релігієзнавча думка, духовні практики та церковне життя в добу українського національно-культурного відродження другої половини XIX століття: інтертекст історіографій / Н. В. Семергей // Історична пам'ять. - 2017. Вип. 37. - С. 110-116.

7. Сніда Є. О. Культурно-національний вектор діяльності православного духовенства Катеринославщини у пореволюційні роки (1917-1918) / Є. О. Сніда // Наддніпрянська Україна: історичні процеси, події, постаті. - 2012. - Вип. 10. C. 259-267.

8. Телуха С. С. Погляди Павла Скоропадського та митрополита Антонія (Храповицького) на актуальні питання церковного будівництва в Україні (квітень-червень 1917 р.) / С. С. Телуха // Вісник НТУ «ХПІ». - 2014. - № 25. - С. 137-144.

9. Ульяновський В. І. Церква в Українській Державі 1917-1920 рр. (доба Гетьманату Павла Скоропадського) / В. І. Ульяновський. - Київ: Либідь 1997. - 320 с.

10. Ульяновський В. І. Церква в Українській Державі 1917-1920 pр. (доба Української Центральної Ради) / В. І. Ульяновський. - Київ: Либідь 1997. - 198 с.

11. Швидкий В. Діяльність О. Г. Лотоцького у вирішенні проблеми Української церкви (1917-1919рр.) / В. Швидкий // Етнічна історія народів Свропи. - 2000. - Вип. 4. - С. 65-70.

12. Щербань М. В. Відносини радянської влади і Російської православної церкви в Україні в контексті формування тоталітарного режиму (1917-1930 рр.): дис. ... канд. іст. наук: 09.00.11 / М. в, Щербань. - Чернівці, 2015. - 268 с.

\section{REFERENCES}

1. Andrusyshyn, B.I. (1997). Cerkva v Ukrainskij Derzhavi 1917-1920 rr. (doba Dyrektorii UNR) [Church in the Ukrainian State of 1917-1920 (the day of the Directory of the UPR)]. Kiev: Lybid [in Ukrainian].

2. Ganzulenko, V.P. (2007). Ukrainska Derzhava 1917-1920 rr. : problema vyrishennja religijnogo pytannja [Ukrainian State 19171920 : the problem of solving religious issues]. Naukovi praci istorychnogo fakultetu Zaporizkogo derzhavnogo universytetu, XXI, 165-167 [in Ukrainian].

3. Kyrydon, A. (2004). Derzhavno-cerkovni vidnosyny v Radjanskij Ukraini 1920-h - 1930-h rokiv: socialnyj vymir [State- 
Church Relations in Soviet Ukraine 1920s - 1930s: Social Dimension]. Problemy istorii Ukrainy: fakty, sudzhennja, poshuky, 12, 234-256 [in Ukrainian].

4. Kyrydon, A. M. (2013). Religijno-cerkovne zhyttja v period Getmanatu : problemne pole vzajemodii [Religious and church life during Hetmanate : a problem field of interaction]. Nacionalna ta istorychna pamjat, 7, 252-259 [in Ukrainian].

5. Kyrydon, A.M. (2017). Cerkva v umovah revoljucijnogo zlamu 1917 roku [The Church was in a revolutionary 1917 revolution]. Proceeding of the Seminar: Ukrainska nacionalna revoljucija 1917-1921 rokiv kriz pryzmu suchasnosti (do 100-richchja podii) - Ukrainian national revolution of 1917-1921 through the prism of the present (to the 100th anniversary of the event). Poltava [in Ukrainian].

6. Semergej, N.V. (2017). Religijeznavcha dumka, duhovni praktyky ta cerkovne zhyttja v dobu ukrainskogo nacionalnokulturnogo vidrodzhennja drugoi polovyny XIX stolittja: intertekst istoriografij [Religious Idea, Spiritual Practice and Church Life in Ukrainian National-Cultural Revival Epoch of the Second Half of hhe 19th Century: Historiography Intertext]. Istorychna pamjat, 37, 110-116 [in Ukrainian].

7. Snida, Je.O. (2012). Kulturno-nacionalnyj vektor dijalnosti pravoslavnogo duhovenstva Katerynoslavshhyny u porevoljucijni roky (1917-1918) [Cultural and national vector of the activity of the Orthodox clergy of Ekaterinoslav in the post-revolutionary years (1917-1918)]. Naddniprjanska Ukraina: istorychni procesy, podii, postati, 10, 259-267 [in Ukrainian].

8. Teluha, S.S. (2014). Pogljady Pavla Skoropadskogo ta mytropolyta Antonija (Hrapovyckogo) na aktualni pytannja cerkovnogo budivnyctva v Ukraini (kviten-cherven 1917 r.) [Views of Pavlo Skoropadsky and Metropolitan Anthony (Khrapovitsky) on topical issues of church building in Ukraine (April-June 1917)]. Visnyk NTU «HPI», 25, 137-144 [in Ukrainian].

9. Uljanovskyj, V.I. (1997). Cerkva v Ukrainskij Derzhavi 1917-1920 rr. (doba Getmanatu Pavla Skoropadskogo) [Church in the Ukrainian State of 1917-1920 (the day of the Hetmanate of Pavlo Skoropadsky)]. Kyiv: Lybid [in Ukrainian].

10. Uljanovskyj, V.I. (1997). Cerkva v Ukrainskij Derzhavi 1917-1920 rr. (doba Ukrainskoi Centralnoi Rady) [Church in the Ukrainian State 1917-1920 (the day of the Ukrainian Central Rada)]. Kyiv: Lybid [in Ukrainian].

11. Shvydkyj, V. (2000). Dijalnist O. G. Lotockogo u vyrishenni problemy Ukrainskoi cerkvy (1917-1919 rr.) [Activities of O. G. Lototsky in solving the problem of the Ukrainian Church (1917-1919)]. Etnichna istorija narodiv Jevropy, 4, 65-70 [in Ukrainian].

12. Shherban, M.V. (2015). Vidnosyny radjanskoi vlady i Rosijskoi pravoslavnoi cerkvy v Ukraini v konteksti formuvannja totalitarnogo rezhymu (1917-1930 rr.) [Relations between Soviet power and the Russian Orthodox Church in Ukraine in the context of the formation of a totalitarian regime (1917-1930)]. Extended abstract of Doctor's thesis. Chernivci: Cherniveckyj nac. un-t im. Jurija Fedkovycha [in Ukrainian].

\section{Семергей Наталія Володимирівна}

Кандидат історичних наук, доцент

Українська медична стоматологічна академія

36011, м. Полтава, вул. Шевченка, 23

\section{Semerhei Nataliya}

$\mathrm{PhD}$ in History, Associate Professor

Ukraine medical stomatological academy

23, Shevchenko st., Poltava, 36011, Ukraine

Email: nsemergey@ukr.netＯRCID: 0000-0002-3095-3131

Цитування: Семергей Н. В. Релігійно-церковний вимір українського національно-культурного відродження 1917-1921 років: концептуалізація наративу сучасної історіографії / Н. В. Семергей // Науково-теоретичний альманах «Грані». - 2018. - Т. 21. - № 7. - С. 63-69.

Citation: Semerhei, N.V. (2018). Relihiino-tserkovnyi vymir ukrainskoho natsionalno-kulturnoho vidrodzhennia 1917-1921 rokiv: kontseptualizatsiia naratyvu suchasnoi istoriohrafii [Religious-church measurement of ukrainian national and cultural revival of 1917-1921: conceptualization of narration of contemporary historiography]. Scientific and theoretical almanac «Grani», 21(7), 63-69. 